Revue bibliographique pour le domaine irano-aryen

\title{
Rüdiger Schmitt. „Die Rolle des Altpersischen im achaimenidischen Palästina“
}

\section{Astrid Nunn}

\section{(2) OpenEdition \\ 1 Journals}

\section{Édition électronique}

URL : http://journals.openedition.org/abstractairanica/48358

DOI : 10.4000/abstractairanica.48358

ISBN : 1961-960X

ISSN : 1961-960X

Éditeur :

CNRS (UMR 7528 Mondes iraniens et indiens), Éditions de l'IFRI

Référence électronique

Astrid Nunn, "Rüdiger Schmitt. „Die Rolle des Altpersischen im achaimenidischen Palästina“ »,

Abstracta Iranica [En ligne], Volume 40-41 | 2019, document 32, mis en ligne le 15 juillet 2019, consulté le 18 avril 2021. URL : http://journals.openedition.org/abstractairanica/48358 ; DOI : https://doi.org/ 10.4000/abstractairanica.48358

Ce document a été généré automatiquement le 18 avril 2021

Tous droits réservés 


\title{
Rüdiger Schmitt. „Die Rolle des Altpersischen im achaimenidischen Palästina“
}

\author{
Astrid Nunn
}

\section{RÉFÉRENCE}

Rüdiger Schmitt. „Die Rolle des Altpersischen im achaimenidischen Palästina“ in Ulrich Hübner, Herbert Niehr (Hg.). Sprachen in Palästina im 2. und 1. Jahrtausend v. Chr. Kolloquium des Deutschen Vereins zur Erforschung Palästinas, 02.-04.11.2012, Mainz. Wiesbaden: Harrassowitz Verlag, 2017, p. 321-342

1 Le passage de l'Empire néo-babylonien à l'Empire achéménide n'a linguistiquement pas apporté de gros changements, la langue officielle et administrative étant l'araméen. Le nombre de personnes maîtrisant le vieux-perse était restreint et le nombre d'objets marqués en vieux-perse par conséquent réduit. Un témoin est le fragment d'un vase en pierre, sur lequel est conservé le début d'une inscription en élamite et babylonien avec le nom d'Artaxerxès. Ce fragment semble provenir de Sepphoris en Galilée. D'autres témoins sont les noms propres iraniens que l'on retrouve dans les textes araméens de Palestine. L'A. en énumère une trentaine, moisson relativement pauvre en comparaison avec les textes araméens d'Egypte. 


\section{AUTEURS}

\section{ASTRID NUNN}

Université de Munich 